\title{
p53 protein overexpression in nasopharyngeal carcinoma in Indonesian patients
}

\author{
A.N.Kurniawan ${ }^{*}$, Anthony S-Y Leong ${ }^{\S}$
}

\begin{abstract}
Abstrak
p53, baik gen maupun proteinnya, merupakan salah satu unsur genetik yang paling banyak diteliti pada penyakit kanker. Oleh karena prevalensi Karsinoma nasofaring (KNF) hanya tinggi pada daerah tertentu saja, terutama di beberapa negara Asia, maka tidak banyak dijumpai tulisan mengenai ekspresi p53 pada KNF dalam kepustakaan internasional. Tulisan ini membahas mengenai ekspresi protein 53 dengan pewamaan imunohistokimia pada 48 pasien KNF Indonesia dan menghubungkannya dengan 2 klasifikasi KNF yaitu menurut WHO dan FORMULASI KERJA. Ekspresi protein p53 ditemukan positif pada karsinoma sel skuamosa, karsinoma tipe A dan karsinoma tipe B berturut turut sebanyak 100\%, 82,6\% dan 62,5\%. Positivitas ekspresi p53 ini berhubungan bermakna dengan klasifikasi FORMULASI KERJA tersebut, sehingga memberikan kesan adanya makna prognostik p53 pada KNF.
\end{abstract}

\begin{abstract}
p53 gene and its protein is one of the most widely studied genetic abnormalities in cancer. However due to the restriction of nasopharyngeal carcinoma (NPC) to certain areas, mostly in Asia, scant attention has been paid to the over-expression of p53 in the high prevalence of NPC in the international literature. This study examined the immunohistological expression of p53 in 48 Indonesian NPC patients and correlated it with two NPC histological classifications. p53 protein over-expression were respectively found in $100 \%, 82.6 \%$, and $62.5 \%$ of squamous cell carcinoma, type A carcinoma and type B carcinoma of Working Formulation classification. This statistically significant correlation gives the impression that p53 may have prognostic relevance in NPC.
\end{abstract}

Keywords: p53 protein, nasopharyngeal carcinoma, immunolabelling, grading

\section{INTRODUCTION}

p53, a 373 amino acid nuclear phosphoprotein was first identified in $1979 .{ }^{1}$ Although initially thought to be an oncogene, it has since been recognized that p53 functions as a tumor suppressor gene. ${ }^{2}$ Numerous subsequent reports have shown that p53 abnormalities occur frequently in a very wide range of tumors. Indeed, abnormalities of p53 appear to be the most common genetic change in human cancer. ${ }^{3}$

Nasopharyngeal carcinoma (NPC) is highly prevalent in several Asian countries and is rare in most Western countries. Because of this difference in prevalence, scant attention has been paid to the over-

\footnotetext{
"Department of Anatomic Pathology, Faculty of Medicine, University of Indonesia, Jakarta, Indonesia

${ }^{\S}$ Hunter Area Pathology Services, Discipline of Anatomical Pathology, University of New Castle, New Castle, NSW, Australia
}

expression of $\mathrm{p} 53$ in NPC, particularly its correlation with histological subtypes.

Based on pathology-based cancer registry statistics, NPC, mostly of the undifferentiated type, was ranked as the fourth most common neoplasm in Indonesia (Department of Health, Indonesian Association of Pathologists, Indonesian Cancer Society. Cancer in Indonesia 1994. Unpublished histopathologic data). This study examined the over-expression of p53 in 48 cases Indonesian NPC patients, employing an immunohistochemical method.

\section{MATERIALS AND METHODS}

The biopsy specimens from 48 NPC cases at the Department of Anatomic Pathology, Faculty of Medicine, University of Indonesia, Jakarta, were examined. Paraffin-embedded specimens were sent to the Institute of Medical and Veterinary Science, Adelaide, Australia (where A S-Y L worked at the time of this research) for immunolabelling. The 
sections were subjected to microwave epitope retrieval as previously described. ${ }^{4}$ Briefly, deparaffinised and rehydrated sections were immersed in $10 \mathrm{mM}$ citrate buffer at $\mathrm{pH} 6.0$, in a closed container, and subjected to microwave irradiation in a domestic microwave oven with a carousel (NEC Model 702, 650 watt) at maximum setting. Five minutes after boiling point was attained, the buffer was maintained at simmering temperature for a further 10 minutes after which the power was switched off. The sections allowed to remain in the hot buffer for another 20 minutes before removal for immunostaining. A standard streptavidin peroxidase technique was employed with anti-p53 monoclonal antibody D07 (Dako, Sydney, Australia) at 1:100 dilution; enzyme digestion was not employed.

The extent of nuclear staining for p53 protein was scored on a scale of $0-4+$ where: 0 represent no staining; $1+=<10 \%$ of tumor cells stained; $2+=10$ $25 \%$ of tumor cells stained; $3+=26-50 \%$ of tumor cells stained; and $4+$ if more than $50 \%$ of tumor cells were stained.

Representative hematoxylin and eosin-stained tumor sections were examined and classified according to the WHO classification ${ }^{5}$ into squamous cell carcinoma (SCC), differentiated nonkeratinizing carcinoma (NKC) and undifferentiated carcinoma (UC). In addition, a classification similar to that proposed by Hsu et al, ${ }^{6}$ and employed in Indonesia ${ }^{7}$ was used. This 'Working Formulation' classification divides NPC into three subtypes (Table 1).

Table 1. Working formulation classification

\begin{tabular}{|c|c|c|c|}
\hline features & $\begin{array}{l}\text { Keratinizing } \\
\text { SCC }\end{array}$ & $\begin{array}{c}\text { Type A } \\
\text { carcinoma }\end{array}$ & $\begin{array}{c}\text { Type B } \\
\text { carcinoma }\end{array}$ \\
\hline $\begin{array}{l}\text { Histologic } \\
\text { pattern }\end{array}$ & Flat pavemented & Syncytial & Syncytial \\
\hline \multirow[t]{2}{*}{ Tumor cells } & $\begin{array}{l}\text { Intercellular } \\
\text { bridges and/or } \\
\text { keratinization }\end{array}$ & $\begin{array}{l}\text { Large, owl-eye } \\
\text { like nuclei }\end{array}$ & $\begin{array}{l}\text { Smaller, more } \\
\text { basophilic } \\
\text { nuclei }\end{array}$ \\
\hline & & $\begin{array}{l}\text { Hyperchrom } \\
\text { atic, spindle } \\
\text { cells }\end{array}$ & $\begin{array}{l}\text { Spindle cell, } \\
\text { fine } \\
\text { chromatin }\end{array}$ \\
\hline Pleomorphism & & Evident & Little \\
\hline Malignancy & High-grade & Intermediate & Low-grade \\
\hline $\begin{array}{l}\text { 5-year } \\
\text { surv.rate }\end{array}$ & $21 \%$ & $30-40 \%$ & $60-70 \%$ \\
\hline
\end{tabular}

\section{RESULTS}

Positive nuclear staining for p53 protein was found in $38(79 \%)$ of the 48 cases, the distribution shown in Table 1. Sixteen (33\%) tumors revealed $1+$ staining and another eight $(17 \%)$ showed $2+$ staining. Eleven $(23 \%)$ tumors showed $3+$ staining and only $3(6 \%)$ showed 4+ staining.

The distribution of p53 over-expression in NPC typed according to the WHO classification is shown in Table 2. Positivity was observed in all nine cases of squamous cell carcinoma although only six showed more than $3+$ positivity in tumor cells. The two cases of differentiated non-keratinizing carcinoma were positive but only as $2+$ or less; on the other hand, the undifferentiated carcinoma group showed a variable degree of p53 staining, with eight.cases showing more than $2+$ cell positivity, six cases $2+$ positivity, and 13 cases less than $1+$ positivity. The remaining 10 cases did not stain at all for p53.

Table 2. p53 immunostaining in Nasopharyngeal Carcinoma

\begin{tabular}{cc}
\hline Percentage of positive tumor cells & Number of cells (\%) \\
\hline 0 & $10(21)$ \\
$1+$ & $16(33)$ \\
$2+$ & $8(17)$ \\
$3+$ & $11(23)$ \\
$4+$ & $3(6)$ \\
\hline Total & $48(100)$ \\
\hline
\end{tabular}

Over expression of p53 protein appeared to show correlation with the 'Working Formulation' classification as proposed by Hsu et $\mathrm{al}^{6}(\mathrm{p}=0.03)$. There was staining in $100 \%$ of the nine cases of keratinizing squamous cell carcinoma, $82.6 \%$ (19 out of 23 cases) of Type A carcinoma and $62.5 \%$ (10 out of 16 cases) of Type B carcinoma (Table 3 ).

Table 3. p53 immunostaining in subtypes of NPC according to the WHO classification

\begin{tabular}{cccc}
\hline p53 immunostaining & \multicolumn{3}{c}{$\begin{array}{c}\text { Histological Subtypes } \\
\text { (WHO classification) }\end{array}$} \\
\cline { 2 - 4 } & SCC & NKC & UC \\
\hline 0 & 0 & 0 & 10 \\
$1+$ & 2 & 1 & 13 \\
$2+$ & 1 & 1 & 6 \\
$3+$ & 5 & 0 & 6 \\
$4+$ & 1 & 0 & 2 \\
\hline Total & 9 & 2 & 37 \\
\hline$\%$ Positive & 100 & 100 & 72,9 \\
\hline
\end{tabular}




\section{DISCUSSION}

The human p53 gene is located at chromosome 17 p13.1 and encodes a 373 amino acid nuclear phosphoprotein, which is involved in the regulation of cell proliferation. ${ }^{8,10}$ Studies in human cancers have revealed that p53 gene is the most frequently affected gene in a wide range of tumors, including cancers of the colon, lung, esophagus, breast, liver, brain, and hematolymphoid malignancies. ${ }^{11,13}$

Chromosomal analysis in several established NPC cell lines have shown multiple genetic aberrations, including chromosome $17 \mathrm{p} 13$.

There are several techniques available for the detection of p53. Detection at the chromosome and gene level can be performed by Southern blotting, in situ hybridization or PCR; whereas, identification of the protein can be done with immunohistochemical techniques which show good correlation with p53 mutation. $^{14,16}$ The monoclonal antibody D07 employed in this study detects both mutant and wild type p53. Wild type p53 has a short half life of less than 30 minutes and is lociated in the nucleus. Mutant p53, on the other hand, has a prolonged half life of several hours, rendering it readily detectable by immunolabelling method. It has been demonstrated that p53 protein may bind to cellular proteins such as the $\mathrm{mdm} 2$ oncogene product and heat shock protein 70 , as well as to several DNA viral proteins including E6 HPV16 protein, ${ }^{17,18}$ SV40T antigen, and E1b protein from adenovirus type 5, all leading to its functional inactivation and stabilization. ${ }^{19}$ While the presence of immunostained p53 protein does not necessarily indicate a gene mutation, the over-expression detected by immunostaining may be a useful indicator of altered wild type p53 function resulting from inactivation and stabilization through one of the preceding mechanisms. It is also recognized that various other cellular insults can induce wild type p53 expression in tumor cells. Within a population of cells in-vivo there is different sensitivity to genotoxic stimuli, yet to be identified, which can stabilize wild type p53, leading to elevated protein levels. ${ }^{20}$ Study by Leung et $\mathrm{al}^{21}$ in EBVassociated gastric carcinoma and head-and neck carcinoma showed a weak to moderate p53 expression, while there was a statistically significant difference of p53 expression between EBVassociated gastric carcinoma and EBV-negative gastric carcinoma. This suggested a non-mutational mechanism of p53 upregulation. Murono et $\mathrm{al}^{22}$ have investigated the association of EBV with status of p53 protein expression in NPC, examined the expression of EBV gene and gene product, p53 protein and bcl-2 protein. Significant correlation was found between the expression of EBV and p53 protein, but not between p53 protein and LMP1. They suggested that some EBV-encoded protein may play a role for nuclear accumulation of p53 protein. Interference by EBV infection may thus cause altered p53 function through epigenetic influence.

There have been few previous reports examining the over-expression of p53 protein in NPC using immunohistochemical methods. Niedobitek et $\mathrm{al}^{23}$ detected p53 over-expression in five of nine EBVnegative squamous cell NPCs and in nine of thirteen EBV-positive cases of undifferentiated carcinoma. In a study of 41 cases from Hong Kong, Porter et $\mathrm{al}^{24}$ found p53 over-expression in $70 \%$ of cases, $12 \%$ showing strong immunostaining for the protein. Our study showed similar result, and strong positivity was found even in a higher percentage ( $29 \%$ of cases showed $3+$ and $4+$ ).

Sheu et $\mathrm{al}^{25}$ using the antibody D07, demonstrated nuclear staining for p53 in 96 (95\%) of 101 lesions. Positive staining in adjacent dysplastic cells was found in $79 \%$ of carcinomas with associated dysplastic epithelium. Based on their findings, these authors suggested that p53 over-expression occurs at an early stage in the development of NPC. Further more, by observing the co-expression of bcl-2 and p53 in 77\% of NPC cases in Taiwan, Sheu et $\mathrm{al}^{26}$ suggested that mutated p53 or altered function of wild-type p53 may contribute to the pathogenesis of NPC, in which bcl-2 and p53 may play a crucial synergistic effect in the carcinogenesis of NPC.

Studies of p53 over-expression in breast carcinoma have suggested that a correlation exists between high levels of expression and advanced stage of disease and metatastic tumor spread. ${ }^{27}$ However, elevated levels of p53 have not been shown to be of prognostic relevance in other epithelial tumors such as small cell carcinoma and adenocarcinoma of the lung, and colonic carcinoma. None of the three immunohistochemical studies in NPC found a correlation between p53 over-expression with survival, potential for metastasis, clinical stage, or histological parameters including grade and lymphocytic infiltration. ${ }^{23,25}$ 

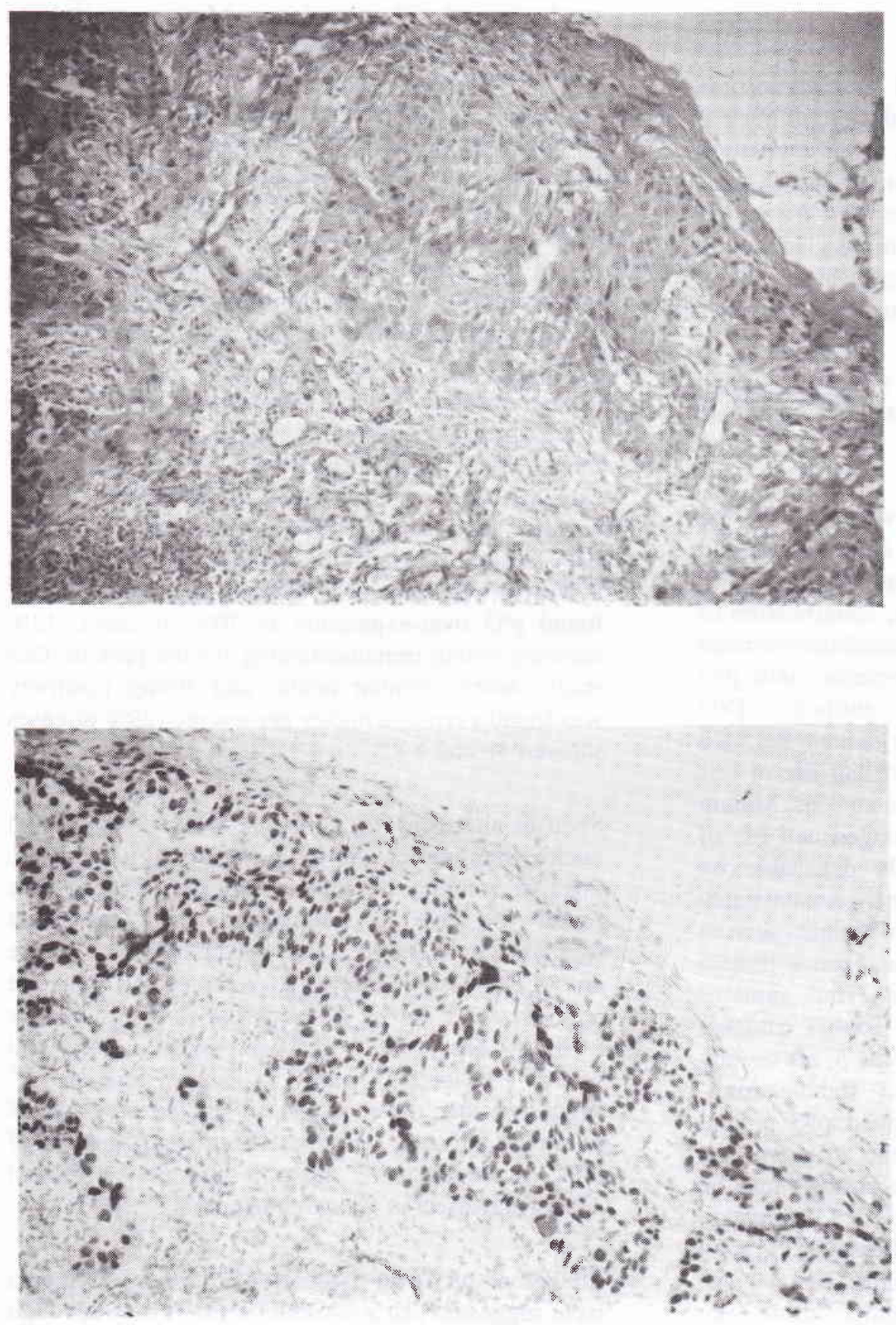

(b)

Figure 1. (a) Keratinizing squamous.cell carcinoma (H\&E) showing $4+$ positivity for p53 protein (b) 


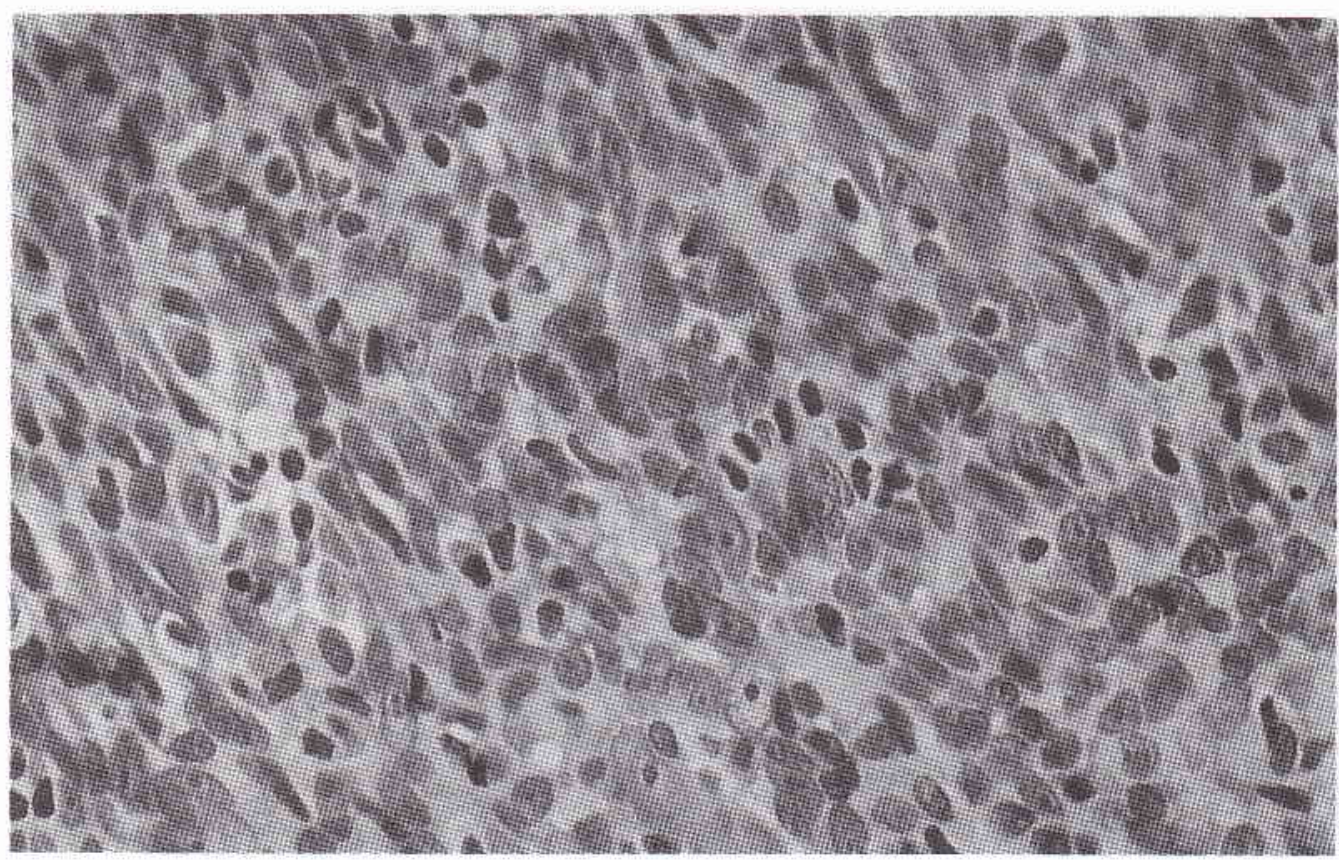

(a)

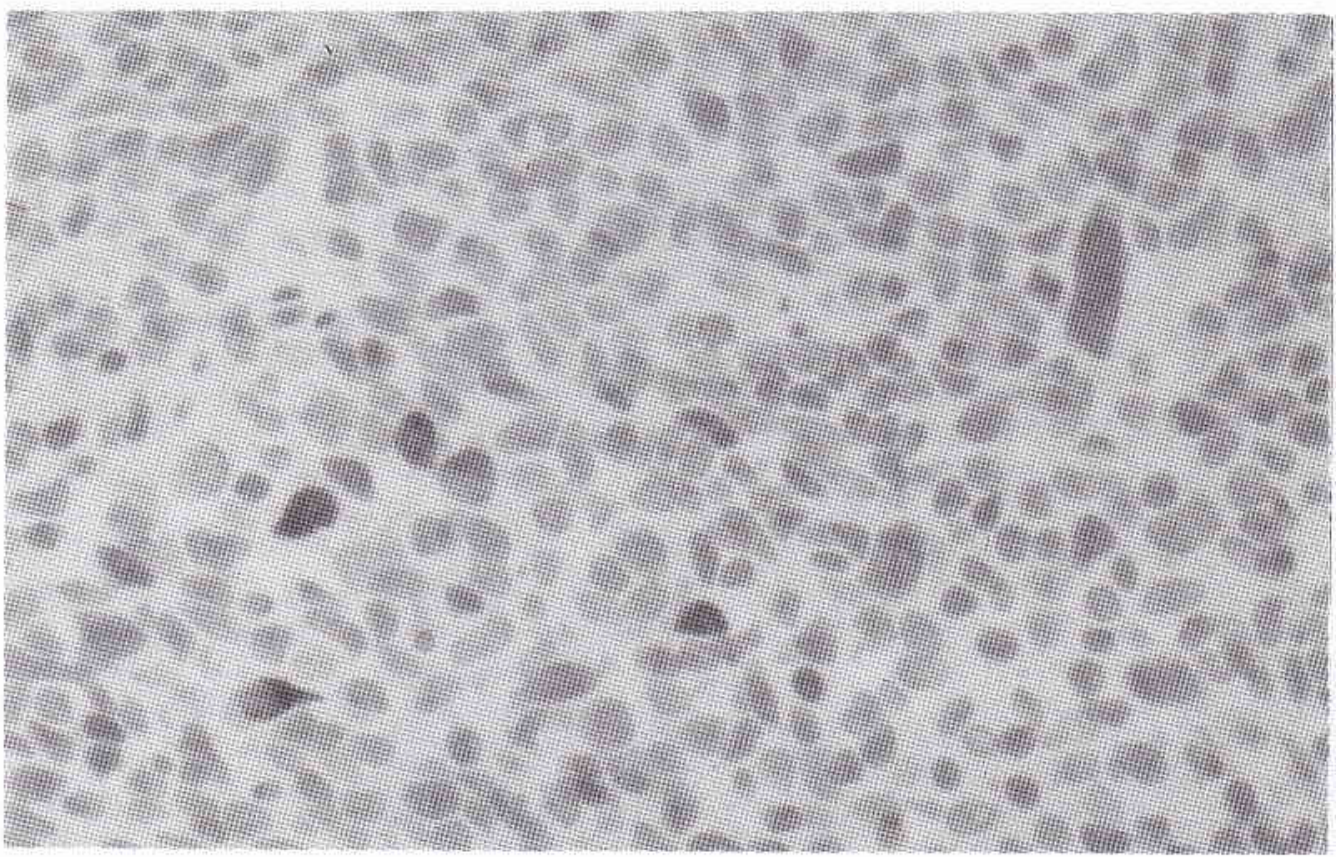

(b)

Figure 2. (a) Type A carcinoma (moderate grade malignancy) (H\&E) showing 4+ positivity for p53 iimunostaining (b) The pleomorphic tumor cells display prominent nucleoli and spindled forms 
Our findings of $79 \%$ positivity in 48 cases of NPC, of which $46 \%$ stained more than $10 \%$ of tumor cells, is in concordance with these previous reports. We did not find a correlation of p53 over-expression with subtypes of NPC when classified according to the WHO system. However, this was not unexpected as the WHO classification is not related primarily to tumor grade, but rather to the morphology of the tumor cells. On the other hand, the Working Formulation as proposed by $\mathrm{Hsu}$ et $\mathrm{al}^{6}$ has been proven to be of prognostic correlation. Employing the alternative Working Formulation on which the Indonesian classification is based, ${ }^{7}$ we found that there was a statistically significant correlation in this study. All cases of keratinizing squamous cell carcinoma (high grade malignancy) stained for $\mathrm{p} 53$, while positivity in Type A carcinoma (intermediate grade malignancy) was $82.6 \%$ and in Type B carcinoma (low grade malignancy) was $62.5 \%$. It is of interest that these three subtypes of NPC showed significant different rates of survival, ${ }^{7}$ therefore suggesting that p53 may have prognostic relevance in NPC.

Masuda et al ${ }^{28}$ who made a clinicopathologic study correlating p 53 , bcl- $2, \mathrm{Ki}-67$, sensitivity to radiation, incidence of distant metastases and survival, reported that NPC patients who were positive for $\mathrm{p} 53$ tended to be resistant to radiotherapy and to have significantly poorer prognosis. They concluded that the enhanced expression of $\mathrm{p} 53$ may be a prognostic factor in NPC patients whose tumor is resistant to DNA-damaging therapy.

The role of p53 as an independent prognostic parameter should be tested through multivariate analysis in conjunction with other prognostic variables and further investigations are necessary to identify appropriate cut-off values of p53 positivity as suggested by Dowell and Hall. ${ }^{15}$ Furthermore, it may be necessary to examine the relevance of not only the percentage of positive staining tumor cells but also to employ some quantitative method which incorporates the intensity of immunostaining such as can be performed with image análysis.

\section{REFERENCES}

1. Lane DP, Crawford LV. T antigen is bound to a host protein in SV 40 tranformed cells. Nature 1979; 278: 261-3.

2. Dowell SP, Hall PA. The clinical relevance of the p53 tumour-suppressor gene. Cytopathology 1994, 5: 133-45.
3. Levine AJ, Momand J, Finlay CA. The p53 tumour suppressor gene. Nature 1991; 351: 453-6.

4. Leong A S-Y, Millios J. An assessment of the efficacy of the microwave antigen-retrieval procedure on arrange of tissue antigens. Appl Immunohistochem 1993; 1: 267-74.

5. Shanmugaratnam $\mathrm{K}$, Sobin LH. Histological typing of tumours of the upper respiratory tract and ear. $2^{\text {nd }} \mathrm{ed}$. Berlin, Heidelberg : Springer Verlag; 1991.

6. Hsu HC, Chen CL, Hsu MW, Lynn TC, Tu SM, Huang SC. Pathology of nasopharyngeal carcinoma. Proposal of a new histologic classification correlated with prognosis. Cancer 1987; 59: 945 - 51.

7. Kurniawan AN, Syafril A, Susworo R. An alternative classification of nasopharyngeal carcinoma as Working Formulation. Med J Univ Indon 1993; 2: 37-46.

8. Isobe M, Emanuel BS, Givol D, Oren M, Croce CM Localization of gene for human p53 tumour antigen to band 17p13. Nature 1986; 320: 84-5.

9. Pietenpol JA, Vogelstein B. No room at the p53 inn Nature 1993; 365: 17-18.

10. Levine AJ, Perry ME, Chang A, Silver A, Dittmer D,Wu $M$ et al. The 1993 Walter Hubert Lecture: the role of the p53 tumour-suppressor gene in tumorigenesis. $\mathrm{Br} \mathrm{J}$ Cancer 1994; 69: 409-16.

11. Hollstein M, Sidransky D, Vogelstein B, Harris CC. p53 mutations in human cancers. Science 1991; 253: 49-53.

12. Lane DP. p53, guardian of the genome. Nature 1992; 368: $15-16$.

13. Zambetti GP, Levine AJ. A comparison of the biological activities of the wild-type and mutant p53. FASEB J 1993; 7: 855-65.

14. Dei Tos AP, Doglioni C, Laurino L, Barbarescki M, Fletcher CDM. p53 protein expression in non-neoplastic lesions and benign and malignant neoplasms of soft tissue. Histopathology 1993; 22: 45-50.

15. Dowell SP, Hall PA. The clinical relevance of the p53 suppressor gene. Cytopathology 1994; 5: 133-45.

16. Baas IO, Mulder J-WR, Offerhaus GJA, Vogelstein B, Hamilton SR. An evaluation of six antibodies for immunohistochemistry of mutant $\mathrm{p} 53$ gene product in archival colorectal neoplasms. J Path 1994; 172: 5-12

17. Lane S, Wells M. Human papillomavirus. Editorial. p53, and cervical neoplasia. J Path 1994; 172: 299-300.

18. Vogelstein B, Kinzler KW. p53 function and dysfunction. Cell 1992; 70: 523-26.

19. Lambkin HA, Mothersill CM, Kelehan P. Variations in immunohistochemical detection of p53 protein overexpression in cervical carcinomas with different antibodies and methods of detection. J Path 1994; 172: 13-18.

20. Hall PA, Lane DP. Editorial. p53 in tumour pathology: Can we trust immunohisto-chemistry?-revisited. J Path 1994; 172: 1-4.

21. Leung SY, Chau KY, Yuen ST, Chu KM, Branicki FJ, Chung LP. p53 overexpression is different in EpsteinBarr virus associated and Epstein-Barr virus negative carcinoma. Histopathology, 1998; 33: 31 1-7.

22. Murono S, Yoshizaki T, Park CS, Furukawa M. Association of Epstein-Bart virus infection with p53 protein accumulation but not bcl-2 protein in nasopharyngeal carcinoma. Histopathology 1999; 34: 432-8. 
23. Niedobitek G, Agathanggelou A, Barber P, Smallman LA, Jones EL, Young LS. P53 overexpression and Epstein -Barr virus infection in undifferentiated and squamous cell nasopharyngeal carcinomas. J Path 1993; 170: $47-61$.

24. Porter MJ, Field JK, Lee JC, Leung SF, Lo D, van Hasselt CA, et al. Detection of the tumour suppressor gene p53 in nasopharyngeal carcinoma in Hong Kong Chinese. Anticancer Res, 1994; 14: 1357-60.

25. Sheu LF, Chen A, Tseng HH, Leu FJ, Lin JK, Ho KC et al. Asssessment of p53 expression in nasopharyngeal carcinoma. Hum Pathol 1995; 26: 380-6.

26. Sheu LF, Chen A, Meng CL, Ho KC, Lin FG, Lee WH. Analysis of bcl-2 expression in normal, inflamed, dysplastic nasopharyngeal epithelia, and nasopharyngeal carcinoma: association with p53 expression. Hum Pathol $1997 ; 28: 556-62$.

27. Davidoff AM, Herndon JE, Glover NS, et al. Relation between p53 overexpression and established prognostic factors in breast cancer. Surgery 1991; 110: 259-264.

28. Masuda M, Shinokuma A, Hirakawa N, Nakashima T, Komiyama S. Expression of bcl-2, p53, and Ki-57 and outcome of patients with primary nasopharyngeal carcinomas following DNA-damaging treatment. Head Neck 1998; 20:640-4. 